\title{
ASSUMPTIONS OF CUSTOMER KNOWLEDGE ENABLEMENT IN THE OPEN INNOVATION PROCESS
}

\author{
Raminta JOKUBAUSKIENE ${ }^{1}$, Rimgailė VAITKIENE ${ }^{2}$ \\ ${ }^{1,2}$ Kaunas University of Technology, Lithuania \\ Corresponding author e-mail: raminta.tvarijonavičiūte@@ktu.edu
}

\begin{abstract}
In the scientific literature, open innovation is one of the most effective means to innovate and gain a competitive advantage. In practice, there is a variety of open innovation activities, but, nevertheless, customers stand as the cornerstone in this area, since the customers' knowledge is one of the most important sources of new knowledge and ideas. Evaluating the context where are the interactions of open innovation and customer knowledge enablement, it is necessary to take into account the importance of customer knowledge management. Increasingly it is highlighted that customers' knowledge management facilitates the creation of innovations. However, it should be an examination of other factors that influence the open innovation, and, at the same time, customers' knowledge management. This article presents a theoretical model, which reveals the assumptions of open innovation process and the impact on the firm's performance.
\end{abstract}

Keywords: Customer knowledge, customer knowledge enablement, customer knowledge management, open innovation, outside-in open innovation process.

JEL Classification: O31.

\section{INTRODUCTION}

The new innovation speed and scale in the last twenty years have shown a dramatic increase (Davenport, Leibold \& Voelpel, 2006). This is partly due to the fact that innovation is the main driver for firms to create value (Prahalad \& Ramaswamy, 2003) and improve the results of the business (Plessis, 2007). However, firms in order to innovate, must figure out strategies how constantly to update their knowledge and apply it in the creation of innovation (Chen et al., 2010). Recently, there is seen an increased focus on customer knowledge and information as one of the main sources of new knowledge and ideas, so more and more firms in their activities use open innovation or user-centric models of innovation (Chesbrough, 2003, 2006). Open innovation model focuses on the use of both internal and external knowledge sources. However, in the innovation literature about external partners, it is emphasized that the customers (Thomke \& von Hippel, 2002; Reichwald \& Piller, 2003; Prahalad, 2004; Lettl, 2007; Piller \& Ihl, 2009) whose contribution appears through their knowledge still have the highest value. Despite the importance of the customers' knowledge in the open innovation process, there is still a huge challenge how to enable the customer knowledge in the open innovation process. 
The one alternative is the right selection and use of customer knowledge (Akhavan \& Heidari, 2007). In this regard, the main role goes for customer knowledge management, which includes the functions related to the main flow of knowledge to acquire and use it. However, it is not enough for an effective customer knowledge management to ensure a smooth and successful open innovation process, since the latter can be influenced by various factors, facilitating the creation of the appropriate environment for customers' knowledge enablement in the open innovation process and giving an easier access and conversion of customer knowledge and ideas, which is needed for the creation of innovation (Hoyer et al., 2010). Thus, the research problem is formulated as a question: what assumptions are necessary for enabling customer knowledge in the open innovation process, which would enable firms to achieve better results?

The aim of the article: to provide the theoretical model of assumptions for customer knowledge enablement in the outside-in open innovation process.

The methods include the systematic and comparative analysis of scientific literature.

\section{OPEN INNOVATION PROCESS IN THE CONTEXT OF CUSTOMERS' KNOWLEDGE ENABLEMENT}

Chesbrough \& Bogers (2014) describe that open innovation is a distributive innovation process based on the orientation of the management of knowledge flows between the firms' boundaries. This means that the open innovation paradigm creates an assumption for firms successfully use of external and internal ideas as well as internal and external routes to market (Chesbrough, 2003). This article focuses on the customers as the most important external source of knowledge and ideas. The growth of their importance is visible by increased customer activity in the innovation process (Laursen \& Salter, 2006; Piller \& Ihl, 2009). Therefore, in terms of customer participation and the integration of knowledge in the open innovation, it is necessary to understand the open innovation process.

Assessing the literature about open innovation processes, there is addition to Chesbrough (2003) who proposed a model of open innovation funnel or other traditional models of innovation, because in open innovation activities, the differences are visible since all activities are substantially different from their own objectives and results.

Gassmann \& Enkel (2005) identified three major open innovation processes, which include: outside-in open innovation, inside-out open innovation, and mixed. Given the fact that this article focuses on customer knowledge enablement in the open innovation process, it will be continued to talk only about the outside-in open innovation process, because this process is directed to the firm's internal processes opening up for a variety of external sources such as intellectual property acquisitions, joint research and development activities, and the involvement of users. Outside-in innovation includes all activities related to the external sources of knowledge. During this process, the firm is controlling the environment in which the acquisition of knowledge and technology from different stakeholders is taking place (Spithoven et al., 2013). 
Meanwhile, inside-out innovations are related to outward technology transfer. During this process, the firm initiates the sale of intellectual property, unused technology solutions sales, and transfer and free open disclosure of innovation to external parties (Spithoven et al. ,2013).

Mixed open innovation process involves both outside-in and inside-out innovation principles to collaborate or participate in other corporate innovation. However, this combination of open innovation processes is the result of alliances, clusters, joint ventures, which focuses on the use of networking (Gassmann \& Enkel, 2005; Chesbrough \& Crowther, 2006).

For the assessment of outside-in open innovation process, it would be useful to review the basic steps. In this case, the ideas of West \& Bogers (2014) fit there the best as they proposed an integrated four-step model for outside-in open innovation (Fig. 1), because basic logic of this model is directed to the use of external knowledge sources. Assuming that business partners, customers and employees in the open innovation processes are quite similar (Van de Vrande et al., 2009), with this model we can look at the external knowledge integration into the firm's internal knowledge when creating new, innovative knowledge, which encourages innovation and success.

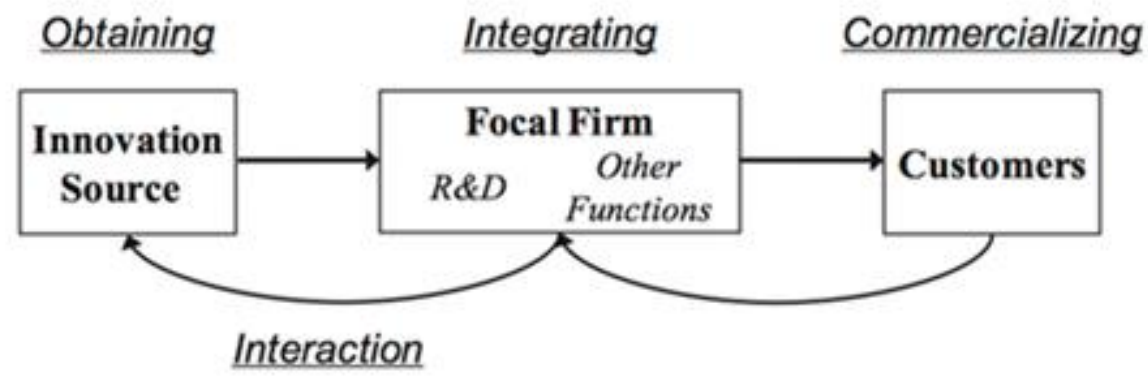

Note. Sources may include suppliers, rivals, complementors, and customers.

Fig. 1. Integrated four-step model for outside-in open innovation process (West \& Bogers, 2014).

This model includes all previous open innovation models that focus on external sources and consist of four stages.

1. Innovation acquisition from external sources. In this case, innovation is understood as new knowledge, ideas or technology. This phase includes the knowledge of the search, sourcing, enablement, promotion and con-tracting.

2. Innovation integration includes the factors that enable the integration of knowledge and factors that act as barriers to the integration of those who change the firm's activities and competencies.

3. Innovation commercialization. Fuller \& Matzler (2007) said that this step involves innovation testing and launch to the market. This phase reveals a key innovation target - value creation.

4. Interaction mechanisms occur in any stage of innovation process. They can occur through feedback, from mutual interactions between co-creator both internally and externally, the external innovation networks, communities, and customers. 
Taking into account the essence of the outside-in open innovation process, when the creation of value is for both the customers and the company. There is innovation initiated by the company and their resources and also customer contribution, more precisely - customer knowledge. A very important point is that firms do not own customers' knowledge and the customers might want not to share it. In addition, each outside-in open innovation process stage requires different customer knowledge (Dahan \& Hauser, 2002). As a result, it is necessary to evaluate all three flows of knowledge (knowledge about customers, knowledge for customers, and knowledge from customers). In this case, customer knowledge management plays purposefully directed functions to absorb and integrate this knowledge into the outside-in open innovation process. It can be assumed that before customers' enablement into innovative activities, firstly, it is appropriate to assess the knowledge of them, because in this way, it is possible to select the right customers and their existing knowledge, which has the greatest potential to create a successful innovation. Customers with appropriate skills, competences and other certain characteristics may have a higher potential for intensity and experiences of innovation activities. It gives the assumption that they could be more useful for open innovation process. Meanwhile, the next stage of the process focuses more on the knowledge from customers and for them, because an intensive sharing and exchange of knowledge occurs.

\section{CUSTOMERS' KNOWLEDGE ROLE IN THE CREATION OF OPEN INNOVATION}

In order to understand the customers' knowledge management role in outsidein open innovation process, it is valuable to define this term briefly. Thus, the main feature of customer knowledge management is that it seeks to acquire knowledge directly from customers, to share them and to develop. In this article, customer knowledge management is understood as a continuous strategic process, in which the firm enables its customers to be less passive buyers and sources of information, and strive to become enabled knowledge partners (Chen \& Huang, 2009) involved in the process of the detection, dissemination and use of knowledge about customers, from customers and for customers. However, successful innovation requires new knowledge approximation, evaluating each stage of the innovation process, because there appears a variety of knowledge of needs and as well as new knowledge integration with the existing enterprise knowledge.

Customer knowledge management improves the firm's absorption capacity (Cohen \& Levinthal, 1990), which allows the firm to acquire external knowledge and to manage and develop it within the firm. Therefore, customer knowledge management is oriented for the identification of efficient external knowledge value and at the same time investing in customer competencies, which are absorbed and used for commercial purposes. In this way, the customer knowledge management is particularly important for the creation of innovation (Belkahla \& Triki, 2011), because in each stage of each open innovation creation process, the integration of new knowledge is necessary in order to create innovation. However, Taherparvar, Esmaeilpour \& Dostar (2014) argue that access to the customer's knowledge 
requires a lot of effort, since it lies in the customer's mind as a tacit knowledge. The conversion of tacit knowledge (experiences, ideas, information, problems, needs, and data) into explicit one (useful ideas from customers to solve problems and ideas for new innovation) and, at the same time, exploiting it is not as simple as it may seem at the beginning because customer knowledge has no direct connection with the firm's knowledge (Fig. 2). Traditionally, knowledge exists in the individual level and is very different, so the creation of new knowledge must go through several stages (Zanini \& Musante, 2013).

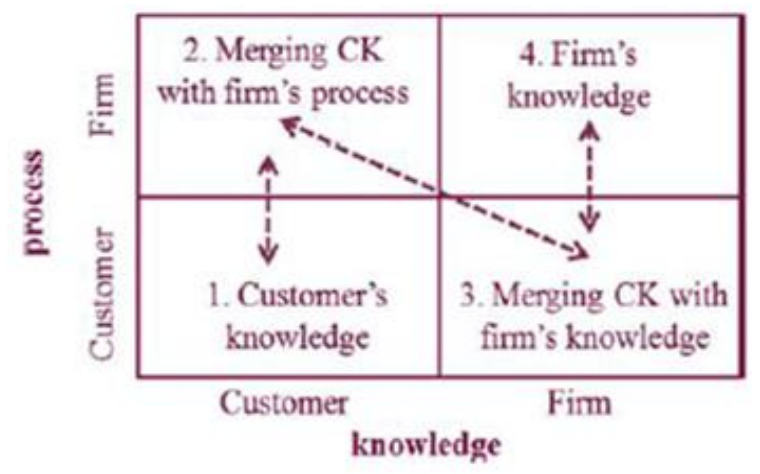

Fig. 2. Conversion of customers' knowledge into firm' knowledge (Taherparvar et al., 2014).

Firstly, customer knowledge must be combined with the firm's processes. Secondly, it has to be connected to the firm's existing knowledge and only then it becomes the firm's knowledge, which is integrated into the creation of innovations. In other words, knowledge has to be taken over from external actors and integrated within the firm between the different functions (Bengtsson et al., 2015).

However, a critical consideration is given to the knowledge flows because they meet different needs of knowledge, which fosters the firms to acquire and use customer knowledge. Three main knowledge flows are distinguished (GarciaMurillo \& Annabi, 2002; Gebert et al., 2003).

Knowledge about customers is necessary in order to select strategic customers for the firm. It includes the current customer needs and requirements, future desires, communications, purchase history, and the purchasing power (Davenport et al., 2001). This knowledge can facilitate the identification of an appropriate customer, which is required for collaboration in open innovation.

Knowledge from customers provides information about products, competitors and the market, which is obtained from the customer estimating the external environment (Garcia-Murillo \& Annabi, 2002). Knowledge flows from customers are evaluated through the prism of the integration of knowledge. Knowledge should be actively absorbed through the knowledge and integrated management tools. Knowledge from customer can be integrated into the development of innovation, ideas generation, and continuous improvement of business products (Thomke \& von Hippel, 2002; Chesbrough, 2003).

Knowledge for customers can be understood as a specific knowledge that meets the needs of customers in relation to the process of innovation, creation of a single 
product, and so on. Knowledge for customers consists of information about products, markets, and suppliers (Garcia-Murillo \& Annabi, 2002).

Each flow of customer knowledge is important for the development of open innovation as it meets the individual needs of the knowledge. For example, using the knowledge from customer and about them for the customer knowledge management provides information about the changing customer needs and knowledge for customers provides them the necessary information. The knowledge for customers includes everything that the firm provides to its customers in order to help them, to satisfy their need, or to increase the level of knowledge. Knowledge from customer is integrated into the development of innovation, ideas generation and continuous improvement of the firm's products (Kristensson, Gustafsson \& Archer, 2004). Knowledge about customers can be used in the choice of appropriate partners for the development of innovation that have the greatest potential for success. In addition, knowledge from customer is the value of long-term in nature, as developing new ideas and to allow the continuous improvement of products. Knowledge about customers creates a short-term value and helps to improve efficiency. Knowledge for customers as well as knowledge about customers create a short-term value by improving the customer experience and the information (Kristensson, Gustafsson \& Archer, 2004). Therefore, customer knowledge, which occurs within the knowledge of what customers want and what they are, is very important for success, because the use of customer knowledge adds value to the organization's internal processes.

However, for the integration of customer knowledge into the innovation process, it is necessary to take into account the additional nuances. As such, it can be stated that alone adequate knowledge flows and the management cannot ensure a smooth and successful open innovation process, since the latter can be strongly influenced by other factors that lead to the customer knowledge potential of innovation success, and may also lead to customer knowledge extraction, integration, and use.

\section{FACTORS FOR THE OUTSIDE-IN OPEN INNOVATION PROCESS AND CUSTOMERS KNOWLEDGE MANAGEMENT FACILITATION}

Despite the benefits of open innovation for firms and taking into the account importance of customer knowledge management, it should be noted that open innovation process can fail if there are no adequate organizational procedures and management (Dahlander \& Piezunka, 2014). This article states that the customer knowledge-based innovation helps to understand how to make better use of innovation in an organization (Yang \& Kang, 2008), but as well other factors are significantly associated with it (not necessarily only the organizational and managerial) which facilitate the open innovation process and are needed for the development of new products. However, in the literature, there is still a lack of complete information, which would disclose summaries list of the outside-in open innovation process factors that influence and facilitate this process. 
In this case, a systematic analysis of the scientific literature was carried out, whose main objective was to reveal the factors influencing the open innovation process and at the same time correlating with the customer knowledge management. The progress of analysis enabled the identification of the factors that may be facilitating the outside-in open innovation process. These factors can be grouped into four main dimensions related to the organizational issues, management issues, operational strategy, and people involved in the open innovation process (Table 1).

Table 1. Factors of open innovation process facilitation

\begin{tabular}{|c|c|c|}
\hline Dimension & Factors & Sources \\
\hline $\begin{array}{c}\text { Organizational } \\
\text { parameters }\end{array}$ & $\begin{array}{l}\text { - Understanding of the nature of } \\
\text { collaboration } \\
\text { - } \text { Trust } \\
\text { - Collaboration experience } \\
\text { - Communication } \\
\text { - Openness } \\
\text { - Mutual exchanges and support } \\
- \text { Knowledge transfer, exchanges and } \\
\text { share } \\
\text { - Win-win situation creation }\end{array}$ & $\begin{array}{l}\text { Buganza et al. (2011), Bogers } \\
\text { (2011), Westergren (2011), Van } \\
\text { de Vrande et al. (2009), Ollila \& } \\
\text { Elmquist (2011), Puck et al. } \\
\text { (2006), Feller et al. (2011), } \\
\text { Muller \& Hutchins (2012), } \\
\text { Lindegaard (2010), Dahlander \& } \\
\text { Gann, 2010), Caputo et al. } \\
\text { (2016), Fertő et al. (2016), Inauen } \\
\text { \& Schenker-Wicki (2011) }\end{array}$ \\
\hline $\begin{array}{l}\text { Management } \\
\text { parameters }\end{array}$ & $\begin{array}{l}\text { - Mechanisms and structures } \\
\text { - Control and coordination } \\
\text { - Clear distribution of roles, works } \\
\text { and responsibilities } \\
\text { - Clear decision making } \\
\text { - Knowledge management systems } \\
\text { - New external knowledge and } \\
\text { competencies application into } \\
\text { internal processes }\end{array}$ & $\begin{array}{l}\text { Feller et al. (2011), Chiaroni et al. } \\
\text { (2010), Buganza et al. (2011), } \\
\text { Bogers (2011), Ollila \& Elmquist } \\
\text { (2011),Chesbrough } \text { et al. (2006), } \\
\text { Dodgson et al. (2006), } \\
\text { Lichtenthaler (2016) }\end{array}$ \\
\hline $\begin{array}{l}\text { Operational } \\
\text { strategy }\end{array}$ & $\begin{array}{l}\text { - } \text { Technological and economic } \\
\text { nature } \\
\text { - } \text { Oriented into reduction of risk and } \\
\text { barriers } \\
- \text { Clear principles of culture for open } \\
\text { innovation activities }\end{array}$ & $\begin{array}{l}\text { Dodgson et al. (2006), } \\
\text { Lindegaard (2010), Vanhaverbeke } \\
\text { (2006), Bigliardi \& Galati (2016) }\end{array}$ \\
\hline $\begin{array}{c}\text { People involved } \\
\text { in the open } \\
\text { innovation } \\
\text { process }\end{array}$ & $\begin{array}{l}\text { - Motivation of partners } \\
\text { - Demographic differences } \\
\text { - Needed competencies, knowledge, } \\
\text { skills, capacities } \\
\text { - } \text { Partner match and selection } \\
\text { - Attitudinal and personality traits } \\
\text { - Committed } \\
\text { - } \text { Readiness and willingness to } \\
\text { develop new skills } \\
\text { - Different knowledge application }\end{array}$ & $\begin{array}{l}\text { Østergaard et al. (2011), Van de } \\
\text { Vrande } \text { et al. (2009), Chatenier } \text { et } \\
\text { al. }(2010), \text { Chesbrough \& } \\
\text { Crowther (2006), Lindegaard } \\
\text { (2010), Rufat-Latre } \text { et al. }(2010), \\
\text { Dahlander \& Gann (2010), } \\
\text { Todorova \& Durisin, (2007), } \\
\text { Savitskaya, Salmi \& Torkkeli } \\
\text { (2010), Ahn et al. (2016), Aloini } \\
\text { et al. (2016), Lichtenthaler } \\
\text { (2016), Newey (2010) }\end{array}$ \\
\hline
\end{tabular}

Note. Systematic analysis of scientific literature was conducted in the EBSCO and Emerald databases for keywords such as "outside-in open innovation process / practice / activity" in the publication title, keywords and abstract, as well as additional keywords "Activities", "good luck / influencers / acting / relevant factors". The analysis included publications in 2004-2017, only in English, based on empirical research publications. 
Factors of organizational block include a wide range of factors that are associated with partners' relationships and the organization. According to Westergren (2011), the firms that tend to be more open could expect that more their ideas will launch the market and the joint efforts with customers will create a winwin situation for both sides. The author has identified five factors that can contribute to the success of open innovation: value creation, collaboration, competencies, complexity, and control. Buganza et al. (2011) emphasize the influence of industrial level variables such as research and development intensity, turbulence and uncertainty, and application of the institutionalization. Lichtenthaler (2016) added a definition of open innovation arguing that this is a systematic knowledge testing, maintenance and use in the firm inside and outside during the whole innovation process. Puck et al. (2006) marked that knowledge transfer and communication openness has a significant impact on different business measures.

Management block. Chesbrough \& Crowther (2006) identified a number of factors that affect the open innovation process. According to the authors, there are particularly important individuals (as they create innovations), networks (as open innovation is defined as cooperation between the internal and external actors), management (as these networks must be coordinated and supervised), national institutions and the innovation systems (as they can influence the ways in which preparing to add a few players in the innovation process). Ollila \& Elmquist (2011) identified three types of management challenges: challenges that arise from the interaction of the firm and the partners, the challenges related to cooperation between the partners, and the challenges associated with operating medium, i. e., the open innovation process.

Operational strategy. Lindegaard (2010) emphasizes the right strategy and the importance of open innovation culture. There are elements that must be included before the open innovation initiative, such as a clear authority, strategic goals, ideas, stakeholder analysis, communication strategy, a common understanding of innovation, organizational approach, which allows adding and obligating all appropriate internal and external actors and approach adaptation, which gives a possibility to innovative. It is very important to have a consistent operational strategy that will enable the company to integrate cooperation activities (Vanhaverbeke, 2006). Bigliardi \& Galati (2016) studied what limits the open innovation process. In this case, they identified four barriers - the knowledge, cooperation, organizational and financial/strategic barriers.

The participants in the innovation process. The attention is a critical factor in the open innovation process (Dahlander \& Gann, 2010). In this case, the attention is defined as observation, coding, interpretation, time and effort to focus on the questions and answers. The attention is to promote the stability of the firm and strengthening the use of existing resources and routines. Of course, in terms of outside-in open innovation for the process necessary for the absorption capacity as the ability to integrate knowledge may vary, because one firm can better use the internal knowledge while the others can use more externally obtained knowledge (Todorova \& Durisin, 2007). Østergaard et al. (2011) study results revealed that there is a positive correlation between demographic diversity and open innovation 
activities. Savitskaya, Salmi \& Torkkeli (2010) revealed that the economic systems and institutions can have a huge effect on the firm's behavior and respect. The importance of uniqueness can vary in the processes of knowledge buying and selling. Thus, the open innovation process is influenced by culture. Ahn et al. (2016) found that the open innovation process is highly dependent on the knowledge management capabilities. Aloini et al. (2016) argue that the appropriate selection of partners positively influence the support of decision processes.

All blocks of factors can influence the open innovation process as independent variables, but it is logical to assume that among them, there are stronger and less influencing factors. And this effect may occur within the knowledge flow quality, intensity, and other similar settings.

\section{THEORETICAL MODEL OF OUTSIDE-IN OPEN INNOVATION PROCESS AND IT'S ASSUMPTIONS OF CUSTOMERS' KNOWLEDGE ENABLEMENT}

Based on the analysis of scientific literature on outside-in open innovation process, customer knowledge management and systematic analysis of scientific literature on the factors positively influencing the outside-in open innovation process at the same correlation to customer knowledge management, a theoretical model was created (Fig. 3). The theoretical model reflects the relationship between all discussed components and enables to reveal new insights or provide solutions to improve the functioning of the model, to achieve better results for a firm. In this case, it shows that outside-in open innovation process directly affects the firm's performance through financial and non-financial aspects. Organizational performance occurs during the intangible value of the firm. In this model, organizational performance was assessed on the basis of research and development activities (Kusunoki et al., 1998), highlighting the following characteristics: innovation activity progress over the past three years, and the open innovation maturity of the firm.

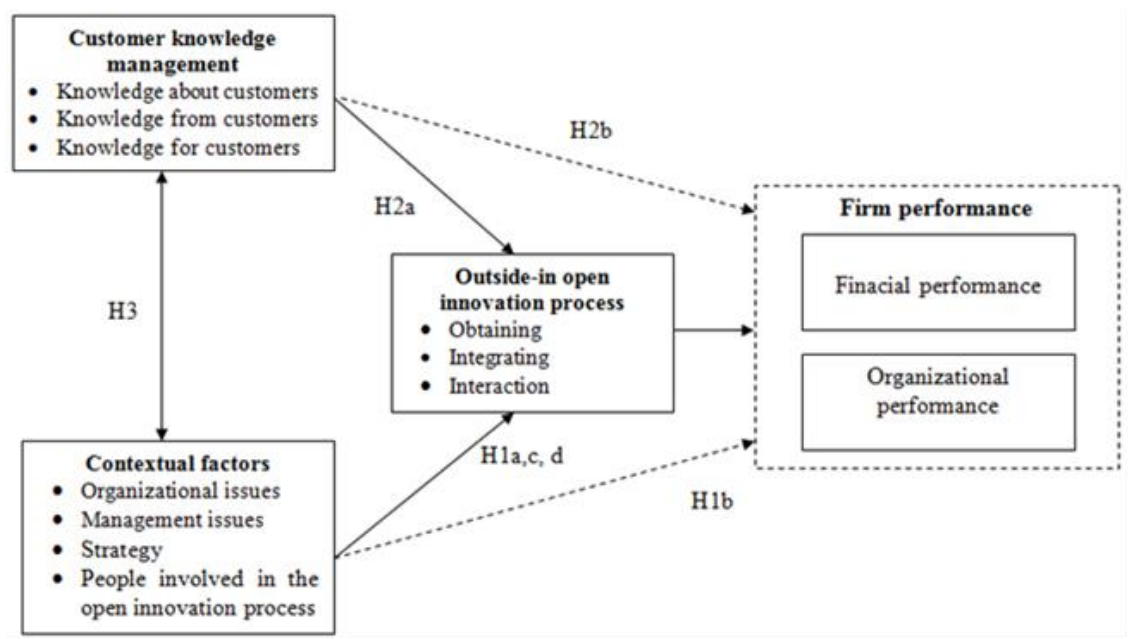

Fig. 3. Theoretical model of outside-in open innovation process and it's assumptions of customers knowledge enablement. 
The financial performance can be both absolute and relative, but in this context, the most important are profitability ratios, which allow the assessment of tangible financial benefits for the firm. In this case, it is assumed that the factors facilitating open innovation process indirectly have a greater impact on organizational performance, since factors are intangible values and only to integrate the innovation process, or acting in synergy with the customer knowledge management gets directly impact. If a customer or a firm has certain parameters, it can lead to better innovation performance, but given the parameters, but without the proper knowledge flows and effectively without first obtaining, converting and using these parameters may not make sense. Therefore, customer knowledge management, in this case, is seen as a major contribution to outside-in open innovation process, and the factors that facilitate this process - as an additional contribution. As a result, the main input provides financial, real tangible benefits such as customer knowledge which is critically important for increasing the percentage of sales (Lichtenthaler, 2016). Meanwhile, an additional contribution - non-financial performance, for example, firms' skills, expertise and management skills - allows creating superior performance characteristics of the product and positive effect on the firm's performance and innovativeness (Lichtenthaler, 2016).

Therefore, the main hypothesis was formulated for the verification of this theoretical model:

- H1A: Contextual factors have a direct and positive influence on the intensity of innovative activities and facilitate the innovation process;

- H1B: Contextual factors affect indirectly but have a greater positive impact on the firm's organizational performance;

- H1c: Contextual factors that are associated with organizational issues potentially have a greater impact on the open innovation process in comparison with others;

- H1d: Contextual factors that are related to operational strategy potentially have less impact on the open innovation process in comparison with others;

- H2A: Customer knowledge flow combination and integration into the open innovation process has a direct and positive influence on the process;

- H2B: Customer knowledge flow combination and integration into the open innovation process have indirect influence but greater positive impacts on the firm's financial performance;

- H3: Synergy of customer knowledge management and contextual factors has a direct and positive effect on the open innovation process and on the firm's financial and organizational performance.

In conclusion, it can be argued that the theoretical model of outside-in open innovation is based on effective customer knowledge management, based on the acquisition and use of appropriate customer knowledge flows as well as additional factors that positively influence the same process of innovation and customer knowledge management. This model allows isolating and developing further research in this context. In addition, the verification of the model and findings of the results obtained could be useful in the selection of appropriate measures, which could foster, on the one hand, higher efficiency of the customer knowledge 
management or factors facilitating the activation of outside-in open innovation process and, on the other hand, the model components common synergies.

\section{CONCLUSION}

This article is oriented into assumptions which could facilitate an open innovation process for better performance of financial and operational results. The primal focus is directed to the open innovation process in order to identify the possible assumptions. It is emphasized that open innovation is characterized by close cooperation with both internal and external sources of knowledge for innovation. In terms of customers and their knowledge enablement, outside-in open innovation process is emphasized as it has a focus on external sources of knowledge. Talking about the integrations of customer knowledge, the most important steps are knowledge acquisition, integration and interaction stages, because they are mainly related to the customers' need for knowledge. However, the knowledge of customer enablement requires effective management of knowledge. As a result, the importance of customer knowledge management is revealed.

Customer knowledge management is related not only to the management of knowledge but also to its utilization. Customer knowledge management helps to improve the firm's abilities that are necessary for the integration of customer knowledge as an open innovation process, acquiring, assimilating, managing and developing it. The firm and customers collectively work together by combining the knowledge and creating a new one. In this work, a critical focus is directed on three main customer knowledge flows: knowledge about customers, knowledge from customers, and knowledge for customers. It can be stated that all knowledge flows are equally important as open innovation requires a close interaction between the firm and the customers. This interaction occurs in a two-sided flow of knowledge when both the firm and the customer are involved. The firm, in turn, tries to extract knowledge from the customer, and about him, while the customer as an equal partner expects to get the same return from a firm - such as knowledge of the process, evaluation, and so on. In addition, knowledge about the customer can be very important for the selection of appropriate partners. Different customer knowledge flows to meet different needs and knowledge potentially have a greater impact on the financial results of the firm.

However, only customer knowledge management for open innovation success may not be sufficient. An open innovation process is influenced by a variety of other factors. As it comes to outside-in open innovation as collaboration with customers, this same process of influencing factors can be strongly correlated with customer knowledge management. In this case, four dimensions of factors related to organizational and management parameters, operational strategy and the people in the innovation process are identified. It is assumed that these factors largely affect organizational performance of the firm, because they are intangible and only are integrated into the innovation process, or acting in synergy with the customer knowledge management and can occur directly. It is also assumed that these factors can cause different effects. In this case, the factors related to organizational 
parameters can have a greater impact when compared with others, because the organizational parameters include the cornerstones of good cooperation practice aspects such as trust, openness, communication, and so on.

Finally, summarized theoretical approaches have been put in the theoretical model, which aims to reveal the discussed assumptions influences and relationships. In this case, the firm's performance is directly affected by the open innovation process, which is exposed to customer knowledge management and contextual factors. It is assumed that the customer knowledge management and contextual factors synergy stimulates a stronger positive impact on outside-in open innovation process and the performance of the firm.

However, this model is based on theoretical considerations, so it would be valuable to verify it empirically in the future. It would allow the selection of appropriate tools and methodologies to improve the efficiency of each component in the model, based on the results obtained.

\section{REFERENCES}

Ahn, J. M., Ju, Y., Moon, T. H., Minshall, T., Probert, D., Sohn, S. Y., \& Mortara L. (2016). Beyond absorptive capacity in open innovation process: the relationships between openness, capacities and firm performance.

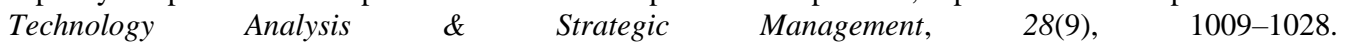
https://doi.org/10.1080/09537325.2016.1181737

Aloini, D., Dulmin, R., Farina, G., Mininno, V., \& Pellegrini, L. (2016). Structured selection of partners inopen innovation: an IF-TOPSIS based approach. Measuring Business Excellence, 20(1), 53-66. https://doi.org/10.1108/MBE-12-2015-0058

Akhavan, P., \& Heidari, S. (2007). Customer Knowledge Management: An Approach for Competitiveness. Modiriat Farda Journal, 5(18), 24-39. https://doi.org/10.4067/s0718-18762015000100006

Bengtsson, L., Lakemond, N., Laursen, K., \& Tell, F. (2015). Managing Knowledge Integration Across Multiple Boundaries in Open Innovation. Paper presented at 16th International CINet Conference, Stockholm, Sweden. https://doi.org/10.1093/acprof:oso/9780198785972.003.0006

Belkahla, W., \& Triki, A. (2011). Customer knowledge enabled innovation capability: proposing a measurement scale. Journal of Knowledge Management, 15(4), 648-674. https://doi.org/10.1108/13673271111152009

Bigliardi, B., \& Galati, F. (2016). Which factors hinder the adoption of open innovation in SMEs? Technology Analysis \& Strategic Management, 28(8), 869-885. https://doi.org/10.1080/09537325.2016.1180353

Buganza, T., Chiaroni, D., Colombo, G., \& Frattini, F. (2011). Organisational Implications of Open Innovation: an Analysis of Inter-Industry Patterns. International Journal of Innovation Management, 15(2), 423-455. https://doi.org/10.1142/S1363919611003210

Bogers, M. (2011). The open innovation paradox: knowledge sharing and protection in R\&D collaborations. European Journal of Innovation Management, 14(1), 93-117. https://doi.org/10.1108/14601061111104715

Caputo, M., Lamberti, E., Cammarano, A., \& Michelino, F. (2016). Exploring the impact of open innovation on firm performances. Management Decision, 54(7), 1788-1812. https://doi.org/10.1108/MD-02-2015$\underline{0052}$

Chiaroni, D., Chiesa, V., \& Frattini, F. (2010). Unravelling the process from Closed to Open Innovation: evidence from mature, asset-intensive industries. $R \& D$ Management, 40(3), 222-245. https://doi.org/10.1111/j.1467-9310.2010.00589.x

Chatenier, E., Verstegen, J. A. A. M., Biemans, H. J. A., Mulder, M., \& Omta, O. S. W. F. (2010). Identification of competencies for professionals in open innovation teams. R\&D Management, 40(3), 271-280. https://doi.org/10.1111/j.1467-9310.2010.00590.x

Chen, C.-J., \& Huang, J.-W. (2009). Strategic human resource practices and innovation performance: the mediating role of knowledge management capacity. Journal of Business Research, 62(1), 104-114. https://doi.org/10.1016/j.jbusres.2007.11.016

Chen, C.-J., Huang, J.-W., \& Hsiao Y.-C. (2010). Knowledge management and innovativeness: The role of organizational climate and structure. International Journal of Manpower, 31(8), 848-870. https://doi.org/10.1108/01437721011088548 
Chesbrough, H. W. (2003). Open Innovation: The New Imperative for Creating and Profiting from Technology. Boston: Harvard Business School Press.

Chesbrough, H. W. (2006a). New puzzles and new findings. In Chesbrough, H. W., West, J. \& Bogers M. (Eds.), (2014). Leveraging External Sources of Innovation: A Review of Research on Open Innovation. J PROD INNOV MANAG, 31(4), 814-831. https://doi.org/10.1111/jpim.12125

Chesbrough, H. W., \& Crowther, A. K. (2006b). Beyond high tech: early adopters of open innovation in other industrines. $R$ and D Management, 36(3), 229-236. https://doi.org/10.1111/j.1467-9310.2006.00428.xs

Chesbrough, H., \& Bogers, M. (2014). Explicating open innovation: Clarifying an emerging paradigm for understanding innovation. In Chesbrough, H., Vanhaverbeke, W., \& West J. (Eds.), New Frontiers in Open Innovation Oxford: Oxford University Press. Retrieved from https://ssrn.com/abstract=2427233

Cohen, W. M., \& Levinthal, D. A. (1990). Absorptive capacity: a new perspective on learning and Innovation. Administrative Science Quarterly, 35, 128-152. https://doi.org/10.2307/2393553

Dahan, E., \& Hauser, J. R. (2002). The virtual customer. Journal of Product Innovation Management, 19(5), 332-353. https://doi.org/10.1111/1540-5885.1950332

Dahlander, L., \& Gann, D. M. (2010). How open is innovation? Research Policy, 39(6), 699-709. https://doi.org/10.1016/j.respol.2010.01.013

Dahlander, L., \& Piezunka, H. (2014). Open to suggestions: How organizations elicit suggestions through proactive and reactive attention. Research Policy, 43(5), 812-827. https://doi.org/10.1016/j.respol.2013.06.006

Davenport, T. H., Harris, J. G., \& Kohli, A. K. (2001). How do they know the customer so well? MIT Sloan Management Review, 9(2), 284-295. Retrieved from http://sloanreview.mit.edu/article/how-do-theyknow-their-customers-so-well/

Davenport, T. H., Leibold, M., \& Voelpel, S. C. (2006). Strategic Management in the Innovation Economy: Strategic Approaches and Tools for Dynamic Innovation Capabilities, Erlangen: Publicis Corporate Publishing.

Dodgson, M., Gann, D., \& Salter A. (2006). The role of technology in the shift towards open innovation: the case of Procter \& Gamble. $R \& D$ Management, 36(3), 333-346. https://doi.org/10.1111/j.14679310.2006.00429.x

Feller, J., Finnegan, P., \& Nilsson, O. (2011). Open innovation and public administration: transformational typologies and business model impacts. European Journal of Information Systems, 20, 358-374. https://doi.org/10.1057/ejis.2010.65

Fertő, I., Molnár, A., \& Tóth, J. (2016). Borderless ideas - open innovation in the Hungarian food chain. British Food Journal, 118(6), 1494-1515. https://doi.org/10.1108/BFJ-10-2015-0399

Fuller, J., \& Matzler, K. (2007). Virtual product experience and customer participation - A chance for customercentred, really new products. Technovation, 27(6-7), 378-387. https://doi.org/10.1016/j.technovation.2006.09.005

Garcia-Murillo, M. \& Annabi, H. (2002). Customer knowledge management. Journal of the Operational Research Society, 53, 875-884. https://ssrn.com/abstract=1328602

Gassmann, O., \& Enkel, E. (2005). Open Innovation Forschung - Forschungsfragen und erste Erkenntnisse. In Weissenberger-Eib, M. (Ed.), Gestaltung von Innovationssystemen, Cactus Group Verlag, Kassel, 3-21. Retrieved from https://www.alexandria.unisg.ch/publications/17076

Gebert, H., Geib, M., Kolbe, L., \& Brenner, W. (2003). Knowledge-enabled customer relationship management: integrating customer relationship management and knowledge management concepts. Journal of Knowledge Management, 7(5), 107-123. https://doi.org/10.1108/13673270310505421

Hoyer, W. D., Rajesh, C., Dorotic, M., Krafft, M., \& Siddarth, S. S. (2010). Consumer Co-Creation in New Product Development. Journal of Service Research, 13(3), 283-296. https://doi.org/10.1177/1094670510375604

Inauen, M., \& Schenker-Wicki, A. (2011). The impact of outside-in open innovation on innovation performance. European Journal of Innovation Management, 14(4), 496-520. https://doi.org/10.1108/14601061111174934

Kusunoki, K., Nonaka, I., \& Nagata, A. (1998). Organizational Capabilities in Product Development of Japanese Firms: A Conceptual Framework and Empirical Findings. Organization Science, 9(6), 699-718. https://doi.org/10.1287/orsc.9.6.699

Kristensson, P., Gustafsson, A., \& Archer, T. (2004). Harnessing the Creative Potential among Users. The Journal of Product Innovation Management, 4-14. https://doi.org/10.1111/j.0737-6782.2004.00050.x

Laursen, K., \& Salter, A. (2006). Open for innovation: The role of openness in explaining innovation performance among U.K. manufacturing firms. Strategic Management Journal, 27(2), 131-150. https://doi.org/10.1002/smj.507

Lettl, C. (2007). User involvement competence for radical innovation. Journal of Engineering and Technology Management, 24(1-2), 53-75. https://doi.org/10.1016/j.jengtecman.2007.01.004 
Lichtenthaler, U. (2016). Determinants of absorptive capacity: the value of technology and market orientation for external knowledge acquisition. Journal of Business \& Industrial Marketing, 31(5), 600-610. https://doi.org/10.1108/JBIM-04-2015-0076

Lindegaard, S. (2010). The Open Innovation Revolution. Hoboken, New Jersey: John Wiley \& Sons.

Newey, L. (2010). Wearning different hats: How absorptive capacity differs in Open innovation. International Journal of Innovation Management, 14(4), 703-731. https://doi.org/10.1142/S1363919610002830

Muller, A., \& Hutchins, N. (2012). Case: Open innovation helps Whirlpool Corporation discover new market opportunities. Strategy \& Leadership, 40(4), 36-42. https://doi.org/10.1108/10878571211242939

Ollila, S., \& Elmquist, M. (2011). Managing Open Innovation: Exploring Challenges at the Interfaces of an Open Innovation Arena. Creativity and Management, 20(4), 273-283. https://doi.org/10.1108/EJIM-082013-0085

Østergaard, C. R., Timmermans, B., \& Kristinsson, K. (2011). Does a different view create something new? The effect of employee diversity on innovation. Research Policy, 40, 500-509. https://doi.org/10.1016/j.respol.2010.11.004

Piller, F. T., \& Ihl, C. (2009). Open Innovation with Customers. Foundations, Competences and International Trends. Technology and Innovation Management Group. RWTH Aachen University. Germany.

Puck, J., Rygl, D., \& Kittler, M. (2006). Cultural antecedents and performance consequences of open communication and knowledge transfer in multicultural process-innovation teams. Journal of Organisational Transformation and Social Change, 3(2), 223-241. https://doi.org/10.1386/jots.3.2.223_1

Plessis, M. (2007). The role of knowledge management in innovation. Journal of Knowledge Management, 11(4), 20-29. https://doi.org/10.1108/13673270710762684

Prahalad, C. K., \& Ramaswamy, V. (2003). The New Frontier of Experience Innovation. Sloan Management Review. Retrieved from https://www.evernote.com/shard/s7/sh/bf8c75fe-8523-42e9-ad650e72f40f407e/5003a5ba28daf0fe617bcc33736a0335/res/b36523a6-2d7f-404f-83d1-856c20a6b466/thenew-frontier-of-experience-innovation.pdf

Prahalad, C. K. (2004). The future of competition: Co-creating unique value with customers. ResearchTechnology Management, 47(3), 62-62.

Reichwald, R., \& Piller, F. T. (2003). Key research issues in user interaction with user toolkits in a mass customisation system. International Journal of Technology Management, 26(5-6). https://doi.org/10.1504/IJTM.2003.003424

Rufat-Latre, J., Muller, A., \& Jones, D. (2010). Delivering on the promise of open innovation. Strategy \& Leadership, 38(6), 23-28. https://doi.org/10.1108/10878571011088032

Savitskaya, I., Salmi, P., \& Torkkeli, M. (2010). Barriers to Open Innovation: Case China. Journal of Technology and Management and Innovation. 5(4), 10-21. https://doi.org/10.4067/s071827242010000400002

Spithoven, A., Vanhaverbeke, W., \& Roijakkers, N. (2013). Open Innovation Practices in SMEs and Large Enterprises. Small Business Economics, 41(3), 537-562. https://doi.org/10.1007/s11187-012-9453-9

Taherparvar, N., Esmaeilpour, R., \& Dostar, M. (2014). Customer knowledge management, innovation capability and business performance: a case study of the banking industry. Journal of Knowledge Management, 18(3), 591-610. https://doi.org/10.1108/JKM-11-2013-0446

Todorova, G., \& Durisin, B. (2007). Absorptive capacity: valuing a reconceptualization. Academy of Management Review, 32(3), 774-786. https://doi.org/10.5465/amr.2007.25275513

Thomke, S., \& von Hippel, E. (2002). Customers as Innovators: A New Way to Create Value. Harvard Business Review, 80, 4.

Vanhaverbeke, W. (2006). The Interorganizational Context of Open Innovation: In Open innovation: Researching a new paradigm. Chesbrough, H., Vanhaverbeke, W. \& West J. (Eds.). Oxford: Oxford University Press, 205-219.

Van de Vrande, V., De Jong, J. P. J., Vanhaverbeke, W., \& De Rochemont, M. (2009). Open innovation in SMEs: trends, motives and management challenges. Technovation, 29(6/7), 423-437. https://doi.org/10.1016/j.technovation.2008.10.001

Westergren, U. H. (2011). Opening up innovation: the impact of contextual factors on the cocreation of ITenabled value adding services within the manufacturing industry. Inf Syst EBus Manage, 9, 223-245. https://doi.org/10.1007/s10257-010-0144-2

West, J. \& Bogers, M., (2014). Leveraging External Sources of Innovation: A Review of Research on Open Innovation. Journal of Product Innovation Management, 31, 5. https://doi.org/10.1111/jpim.12125

Yang, S., \& Kang, H. H. (2008). Is synergy always good? Clarifying the effect of innovation capital and customer capital on firm performance in two contexts. Technovation, 28(10), 667-678. https://doi.org/10.1016/j.technovation.2008.01.004

Zanini, M. T., \& Musante, M. (2013). Trust in the knowledge economy. Journal of Business \& Industrial Marketing, 28(6), 487-493. https://doi.org/10.1108/JBIM-04-2013-0102 


\section{AUTHORS' SHORT BIOGRAPHY}

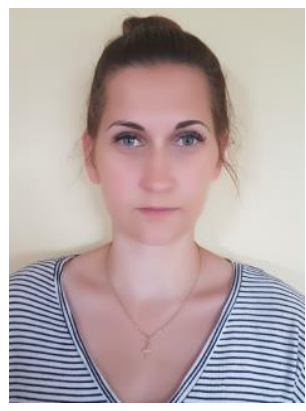

Raminta Jokubauskienė received the Master's degree in management and business administration from Kaunas University of Technology in 2012. At present, she is a Ph.D. candidate at the Department of Strategic Management, the School of Economics and Business at Kaunas University of Technology.

Her main fields of scientific interest are open innovation, customer knowledge management, and co-creation.

Address: Gedimino Str. 50, LT-44239, Kaunas, Lithuania.

Phone: +370 67877361 .

E-mail: raminta.tvarijonaviciute@ktu.edu

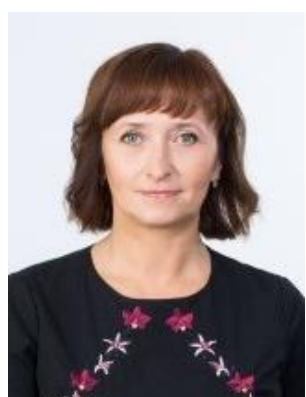

Rimgailè Vaitkienè is a Professor at the Accounting Department of Kaunas University of Technology.

Her main fields of scientific interest are organization management, consumer integration in innovations, strategic marketing management, and research methodology for business and management.

Address: Gedimino Str. 50, LT-44239, Kaunas, Lithuania.

Phone: +370 37300122 .

E-mail: rimgaile.vaitkiene@ktu.lt 